\title{
Influenza A (H5N1) Virus
}

National Cancer Institute

\section{Source}

National Cancer Institute. Influenza A (H5N1) Virus. NCI Thesaurus. Code C123490.

A strain of avian influenza A virus. This strain has caused major outbreaks in domestic poultry in parts of Asia and the Middle East and can cause infections in humans. 